\title{
Effects of Gamma Irradiation on Agromorphological Characteristics of Okra (Abelmoschus esculentus L. Moench.)
}

\author{
Aaron Tettey Asare, ${ }^{1}$ Francis Mensah, ${ }^{1}$ Samuel Acheampong, \\ Elvis Asare-Bediako, ${ }^{2}$ and Jonathan Armah $^{3}$ \\ ${ }^{1}$ Department of Molecular Biology and Biotechnology, School of Biological Sciences, University of Cape Coast, Cape Coast, Ghana \\ ${ }^{2}$ Department of Crop Sciences, School of Agriculture, University of Cape Coast, Cape Coast, Ghana \\ ${ }^{3}$ Biotechnology and Nuclear Agricultural Research Institute, Ghana Atomic Energy Commission (GAEC), \\ P.O. Box LG80, Legon, Accra, Ghana
}

Correspondence should be addressed to Aaron Tettey Asare; aasare@ucc.edu.gh

Received 25 April 2017; Accepted 5 July 2017; Published 3 August 2017

Academic Editor: Othmane Merah

Copyright (C) 2017 Aaron Tettey Asare et al. This is an open access article distributed under the Creative Commons Attribution License, which permits unrestricted use, distribution, and reproduction in any medium, provided the original work is properly cited.

Cultivation of okra in Ghana is challenged by low yield due to lack of improved varieties. Gamma irradiated okra seeds can generate genetic variability to improve the crop. Samples of 150 seeds, each of okra genotype, UCCC6, were irradiated with 400 Gy to 1000 Gy using cobalt 60 source at a dose rate exposure of $121.58 \mathrm{~Gy} / \mathrm{hr}$. There were 40 stands comprising single plant per stand in three replications per treatment in a randomized complete block design outlay. Seedling survival, plant height, number of leaves, stem diameter, number of branches, leaf length and width, days to $50 \%$ flowering, number of fruits, length and weight of fruit, number of seeds, and 100 -seed weight decreased significantly $(P \leq 0.05)$ with increasing doses of gamma rays. Seedling survival was highest (88\%) at $400 \mathrm{~Gy}$, followed by control (81\%). However, $600 \mathrm{~Gy}, 800 \mathrm{~Gy}$, and $1000 \mathrm{~Gy}$ had $61 \%$, $41 \%$, and $17 \%$ seedling survival, respectively, with $\mathrm{LD}_{50}$ at $720 \mathrm{~Gy}$. Significant $(P \leq 0.05)$ correlations existed between growth and yield components. Optimum growth and yield in okra were induced by $400 \mathrm{~Gy}$ but the higher doses had growth retardation effects and the induced variability can be assessed at $\mathrm{M}_{2}$ generation

\section{Introduction}

Okra (Abelmoschus esculentus L. Moench.) is a multipurpose crop due to various uses of the fresh leaves, buds, flowers, pods, stems, and seeds [1]. It is a fresh vegetable found in almost all markets in Ghana due to its strong commercial value for resource poor farmers and its importance as food in rural and urban communities. Okra is a good source of many nutrients including carbohydrates, proteins (rich in lysine and tryptophan), vitamins A, B, and C, dietary fibre, calcium, zinc, folic acid, and iodine [2-4]. It has potential mucilage for medicinal applications [5], as a protective food additive against irritating and inflammatory gastric diseases [6]. Okra is also used as a blood plasma replacement or blood volume expander and also binds cholesterol and bile acid carrying toxins dumped into it by the liver $[7,8]$.
Despite the importance, the yield of okra in Ghana is low due to lack of improved varieties to mitigate climate change, diseases, pests, and edaphic factors. However, mutation breeding has proven to be a useful technique in plant improvement. Gamma rays represent one of the important physical agents used to improve the characters and productivity of many plants such as rice, maize, bean, cowpea, and potato [9]. Irradiation has also been successfully used to induce mutation in breeding of various crops and ornamental plants [10] and has proven an adept means of encouraging the expression of recessive genes and producing new genetic variations [10-12].

Doses of gamma irradiation positively affect growth and seed yield of okra (Abelmoschus esculentus L.) [13]. Dubey et al. [14] showed that plant height and branches per plant were increased when okra (Abelmoschus esculentus) seeds 
were irradiated by different doses of gamma rays. It has been indicated that the effect of interaction between doses of gamma rays and okra genotypes was highly significant $(P \leq$ $0.05)$ in the number of pods per plant and seeds per pod [15]. Despite its importance as a vegetable crop, okra has received little attention in terms of breeding for yield and quality improvement in Ghana. The need to explore gamma radiation technology to induce mutation in okra is to create variable genotypes and identify desirable traits for improvement of the crop. The main objective of this study was to assess the effects of gamma irradiation on growth and yield of okra.

\section{Materials and Methods}

Cobalt 60 source was used to treat okra seeds at the Radiation Technology Centre, Ghana Atomic Energy Commission in Accra, Ghana. The radiator has a pneumatic system which carried the plaque source rack $\left(1 \times 1 \mathrm{~m}^{2}\right)$ containing CoS$43 \mathrm{HH}$ source types from the rest position to the irradiation position in the irradiation chamber and a transport system for rotating the tote boxes to ensure a dose uniformity ratio of approximately unity. The cobalt 60 category IV wet storage gamma irradiation source has a current strength of $26 \mathrm{Kci}$ with a dose rate of $1.55 \mathrm{KGy} / \mathrm{hr}$ around the shroud. The seeds of okra genotype, UCCC6, were subjected to $0 \mathrm{~Gy}, 400 \mathrm{~Gy}$, $600 \mathrm{~Gy}, 800 \mathrm{~Gy}$, and $1000 \mathrm{~Gy}$ doses of gamma irradiation. Four (4) samples of 150 dry okra seeds were each treated at a position of $71 \mathrm{~cm}$ from the floor and $110 \mathrm{~cm}$ from the gamma irradiation source in the irradiation chamber. A dosimeter was attached to each okra sample and exposed to gamma radiation at a dose rate of $121.58 \mathrm{~Gy} / \mathrm{hr}$. Ferrous ammonium sulphate (Fricke) dosimeters were used to determine the absorbed dose in the 400 Gy treatment sample. The Fricke dosimeters were removed from the okra sample after the irradiation period. The absorbed dose was then determined using a calibrated spectrophotometer (model UVD-3200, Labomed, Incorporated). Ethanol-chlorobenzene (ECB) dosimeters were used to determine the absorbed dose in the $600 \mathrm{~Gy}, 800 \mathrm{~Gy}$, and $1000 \mathrm{~Gy}$ treatment samples. The ECB dosimeters were removed from the okra samples after the irradiation period. The absorbed dose was determined using a calibrated readout instrument (High Frequency Dosimeter System, Model 2131, version 2.5, Sensolab Ltd.).

The treated seeds together with the control were sown randomly in rows in five blocks. The field experiment was carried out at the Teaching and Research Farm of the School of Agriculture, University of Cape Coast. Sowing was done at the rate of 3 seeds per hole at planting distance of $50 \mathrm{~cm} \times$ $50 \mathrm{~cm}$ within and between rows. There were three replications arranged in a randomized complete bock design outlay. Hand irrigation was carried out at the experimental site whenever necessary. The seedlings were thinned out to one per stand at 6th week after sowing to ensure good establishment of single plant per stand. The field was weeded with cutlasses and hoe every 3 weeks. The NPK $(15: 15: 15)$ fertilizer was applied at a rate of $8 \mathrm{mg}$ per stand at week 6 after sowing. The insecticide, PAWA 2.5 EC (NOVA AGRO, HK Ltd, South Africa), was used to spray plants at the rate of $35 \mathrm{ml} / 15 \mathrm{~L}$ water in the 9 th,

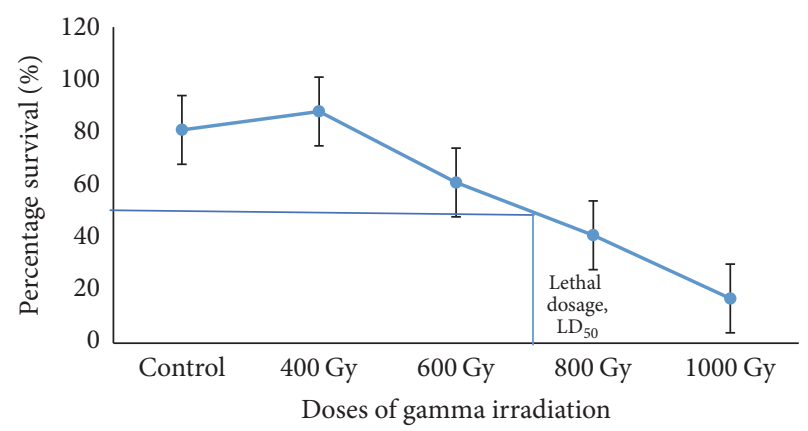

Figure 1: Percentage survival of okra seedlings in response to gamma irradiation.

12th, and 15th week to control insects. Harvesting was carried out when pods reached the marketable harvest index (when the fruit appeared freshly bright green with small green seeds). The effects of gamma irradiation on seed germination or seedling survival, leaf production, stem diameter, plant height, leaf length, leaf width, days to $50 \%$ flowering, number of pods, length of fruit, weight of fruit, number of seeds, and 1000 -seed weight were assessed. The number of seedlings that emerged per treatment was obtained through daily counts of emerging shoots above the soil surface at 5-21 days after planting.

The seedling emergence or percentage survival was used to predict the lethal dose for the okra genotype, UCCC6. The fresh and dried fruits harvested were weighed using an electronic balance (Radwag, WPT 12C1, Poland). All the quantitative data were subjected to one-way analyses of variance (ANOVA) using Minitab 15 release software and the means were separated with Fisher's Least Significant Difference (LSD).

\section{Results and Discussions}

On the whole, growth and yield characteristics of okra were significantly $(P \leq 0.05)$ retarded with increasing doses of gamma irradiation. The effects of gamma irradiation significantly $(P \leq 0.05)$ reduced and delayed seed germination in okra. The $600 \mathrm{~Gy}, 800 \mathrm{~Gy}$, and $1000 \mathrm{~Gy}$ retarded seed germination and seedling survival significantly $(P \leq 0.05)$ compared to the control. The highest rate of percentage seedling survival was observed for $400 \mathrm{~Gy}$ at $88 \%$, which was closely followed by the control (81\%), while $600 \mathrm{~Gy}$, $800 \mathrm{~Gy}$, and $1000 \mathrm{~Gy}$ recorded $61 \%, 41 \%$, and $17 \%$, respectively (Figure 1). Indeed, the gamma rays might have induced lethality in the okra with $\mathrm{LD}_{50}$ determined as $720 \mathrm{~Gy}$ (Figure 1). Increasing doses of gamma irradiation was associated with significant $(P \leq 0.05)$ corresponding low seed germination probably due to the effect of mutagens on meristematic tissues of the seed as well as chromosomal aberrations and interruptions in DNA replications and growth regulators. In okra, germination percentage decreased with increase in dosages of gamma irradiation [16]. In the current study, low germination reflected in low seedling survival as doses of gamma irradiation increases. Low germination percentage with increasing doses of gamma irradiation has been reported 


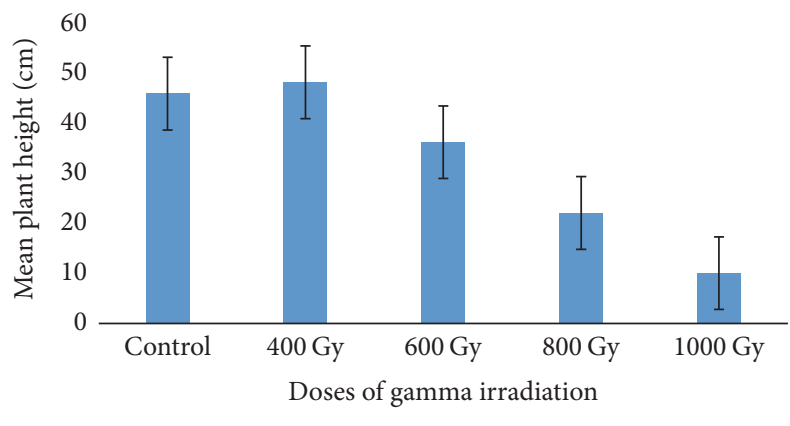

FIGURE 2: Effect of gamma irradiation on okra plant height.

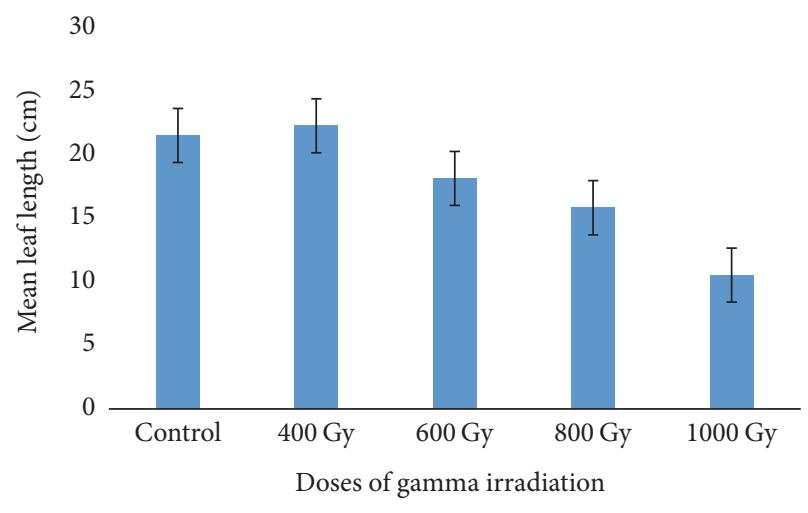

FIGURE 3: The effect of gamma irradiation doses on leaf length.

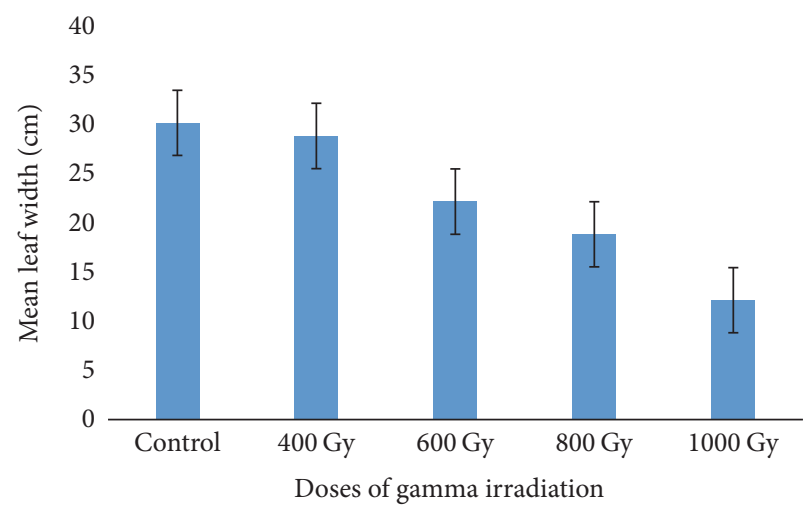

FIgURE 4: The effect of gamma irradiation on mean leaf width.

to the control (Figures 3 and 4). Similarly, the inhibitory effects of increased doses of gamma rays on leaf growth of an okra variety Arka Anamika has been reported [39]. However, lower doses of gamma rays had stimulatory effects on average length and width of leaves while higher doses had inhibitory effects. In this connection, it has been reported that increase in plant sensitivity after gamma irradiation may probably be due to reduced level of endogenous growth regulators, such as cytokinins, as a result of breakdown or lack of synthesis [28]. The average leaf width significantly $(P \leq 0.05)$ correlated positively with leaf length $(r=0.987)$ and plant height $(r=$ 0.981 ) which may present plants with wider surface area for photosynthesis.

The average number of leaves produced decreased significantly $(P \leq 0.05)$ with increased doses of gamma irradiation. Highest average number of leaves (30.67) was observed for plants developed with $400 \mathrm{~Gy}$ exposure and the lowest (16.25) with 1000 Gy exposure (Figure 5). These results were consistent with those obtained by others $[33,40]$, and the high levels of irradiation doses adversely reduced the number of leaves. Production of the growth regulator, kinetin, might have been stimulated, which may be responsible for the increased number of leaves. Similarly, [14] showed an increase in the number of leaves when okra seeds were irradiated with different doses of gamma rays. Indeed, the number of leaves positively correlated with leaf length $(r=0.970)$ and

leaf width $(r=0.931)$. Growth in stem thickness of okra
Irradiation doses of $600 \mathrm{~Gy}, 800 \mathrm{~Gy}$, and $1000 \mathrm{~Gy}$ sign cantly $(P \leq 0.05)$ reduced leaf length and width as compared 


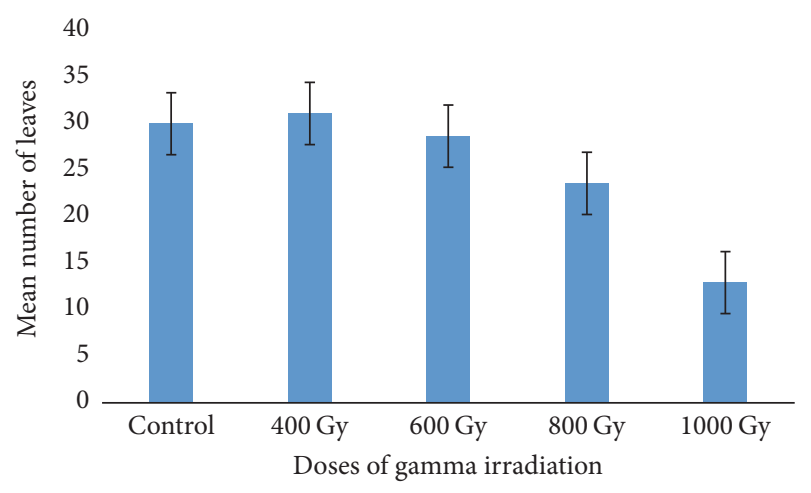

FIGURE 5: The effect of gamma irradiation on mean number of leaf.

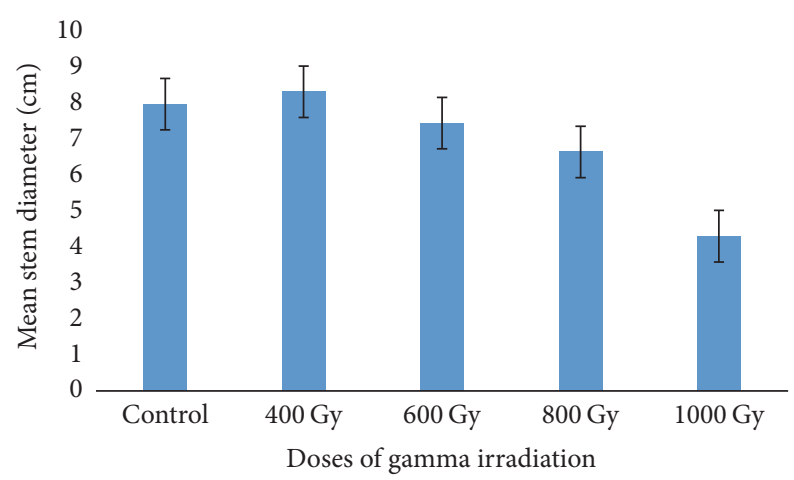

FIGURE 6: The effect of gamma irradiation doses on mean stem diameter.

in response to doses of gamma rays differed significantly $(P \leq 0.05)$ among the treatments. The effect of $1000 \mathrm{~Gy}$ significantly $(P \leq 0.05)$ reduced the stem diameter as compared with control, followed by 600 and $800 \mathrm{~Gy}$, respectively (Figure 6). However, $400 \mathrm{~Gy}$ induced the highest stem thickness compared to the other treatments. The fact that stem diameter positively correlated with plant height $(r=$ $0.959)$, leaf length $(r=0.981)$, leaf width $(r=0.945)$, and number of leaves $(r=0.997)$ suggests vigorous growth with sustained stability against lodging.

Different doses of gamma rays induced different characteristic branching in okra. The $400 \mathrm{~Gy}$ plants exhibited a Y-shaped branching. In response to $600 \mathrm{~Gy}, 800 \mathrm{~Gy}$, and $1000 \mathrm{~Gy}$, the main shoot or stem bifurcated in two parallel branches, which are further divided with repeated pattern of Y-shaped branching. Mishra [41] noticed the peculiar Yshaped branching in okra plants derived from seeds treated with 0.4 and $0.6 \mathrm{kGy}$ doses. The control plants did not show stem branching as observed in the current study. The $400 \mathrm{~Gy}$ dose had average of 10 plants with the stem branched whereas $600 \mathrm{~Gy}, 800 \mathrm{~Gy}$, and $1000 \mathrm{~Gy}$ had 35, 28, and 14 plants associated with stem branching, respectively.

The okra plants differed significantly $(P \leq 0.05)$ in response to days to $50 \%$ flowering among the various treatments. The 400 Gy significantly $(P \leq 0.05)$ decreased the number of days (92) to attain $50 \%$ flowering. On the contrary, $600 \mathrm{~Gy}, 800 \mathrm{~Gy}$, and $1000 \mathrm{~Gy}$ increased the number of days

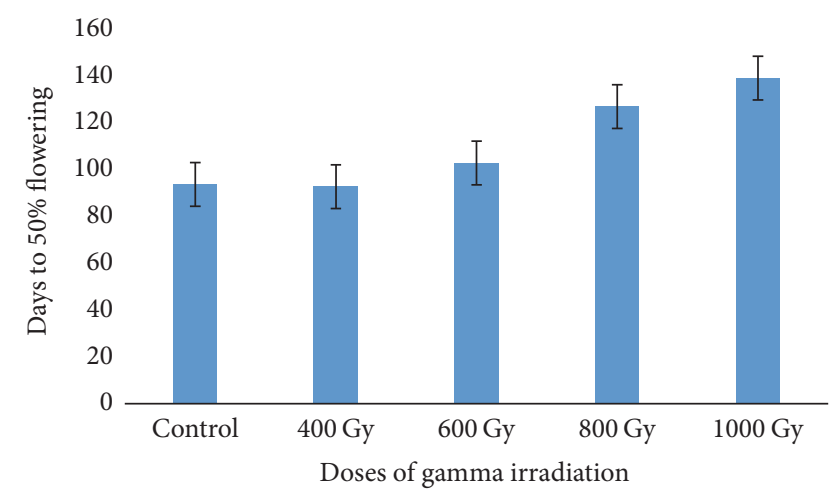

FIGURE 7: Effect of gamma irradiation on number of days to $50 \%$ flowering in okra.

to $50 \%$ flowering (Figure 7). A dose of $1000 \mathrm{~Gy}$ induced the longest number of days to $50 \%$ flowering (128 days) compared to $400 \mathrm{~Gy}$ (92 days) and the control plants (93 days) (Figure 7). However, a gradual decrease in days to flowering occurs as radiation dose increased [42]. Days to $50 \%$ flowering had significant $(P \leq 0.05)$ positive correlation with plant height, leaf length $(r=0.940)$, leaf width $(r=$ $0.917)$, number of leaves $(r=0.890)$, and stem diameter $(r=0.898)$. The late flowering responses could have also been influenced by the delay in seed germination and growth of plants with increasing doses of gamma irradiation.

On the whole, 400 Gy significantly $(P \leq 0.05)$ increased the number of fruits per plant up to 52.86 , whereas $600 \mathrm{~Gy}$, $800 \mathrm{~Gy}$, and $1000 \mathrm{~Gy}$ significantly $(P \leq 0.05)$ reduced the number of fruits from 25.43 and 8.43 to 2.71 , respectively (Table 1). Increased number of fruits per plant as a result of gamma irradiation has also been reported [14, 43-45]. It has been observed that $400 \mathrm{~Gy}$ exposure stimulated increase in number of fruits per plant in the current study. Correlations between number of fruits and leaf length (0.936), leaf width $(r=0.929)$, number of leaves $(r=0.855)$, stem diameter $(r=0.873), 50 \%$ flowering $(r=0.991)$, number of seeds $(r=0.967)$, and weight of dried fruit $(r=0.953)$ were positive and significant $(P \leq 0.05)$.

There were significant differences $(P \leq 0.05)$ in the length of fresh fruits of okra in response to the different doses of gamma rays. The $800 \mathrm{~Gy}$ and $1000 \mathrm{~Gy}$ significantly $(P \leq$ $0.05)$ reduced the average length of fresh fruit. Maximum fruit length of $7.88 \mathrm{~cm}$ was observed in response to $400 \mathrm{~Gy}$ exposure and lowest fruit length of $6.66 \mathrm{~cm}$ was in response to $1000 \mathrm{~Gy}$ exposure (Table 1). Indeed, $400 \mathrm{~Gy}$ exposure was found to increase fruit characters such as length [46]. A significant reduction $(P \leq 0.05)$ in average fresh fruit weight from $14.07 \mathrm{~g}, 12.72 \mathrm{~g}$, and 9.51 to $7.16 \mathrm{~g}$ was observed with increase in irradiation doses $(0.0 \mathrm{~Gy}, 600 \mathrm{~Gy}$, and $800 \mathrm{~Gy}$ to $1000 \mathrm{~Gy}$ ), respectively (Table 1). In addition, there were significant reduction $(P \leq 0.05)$ in fruit dry weight, 100 -seed dry weight, and number of seeds per pod with increasing doses of gamma irradiation. However, weight of the fresh fruits per plant (14.13 g) developed from $400 \mathrm{~Gy}$ exposure was similar to that of the control $(14.07 \mathrm{~g})$. The same pattern of response was observed for fruit dry weight, 100-seed weight, and 
TABLE 1: The effects of doses of gamma irradiation on fruit and seed yield in okra.

\begin{tabular}{|c|c|c|c|c|c|c|}
\hline $\begin{array}{l}\text { Treatment } \\
\text { (Gy) }\end{array}$ & Number of fresh fruit & Fresh fruit length $(\mathrm{cm})$ & Fresh fruit weight (g) & Dried fruit weight $(\mathrm{g})$ & Number of seeds & $\begin{array}{c}\text { 100-seed } \\
\text { weight } \\
\text { (g) }\end{array}$ \\
\hline 0.0 & 38.71 & 7.57 & 14.08 & 10.14 & 61.04 & 4.44 \\
\hline 400 & 52.86 & 7.88 & 14.13 & 10.24 & 63.46 & 4.60 \\
\hline 600 & 25.43 & 7.62 & 12.72 & 5.73 & 29.97 & 3.76 \\
\hline 800 & 8.43 & 6.86 & 9.51 & 4.34 & 19.17 & 3.36 \\
\hline 1000 & 2.71 & 6.67 & 7.17 & 3.90 & 9.00 & 1.68 \\
\hline$(P<0.05)$ & 11.68 & 0.68 & 2.27 & 1.79 & 11.09 & 0.25 \\
\hline
\end{tabular}

TABLE 2: Correlations of growth and yield component analysis in okra.

\begin{tabular}{|c|c|c|c|c|c|c|c|c|c|c|c|}
\hline$\overline{\mathrm{PH}}$ & LL & LW & NOL & SD & $50 \% \mathrm{~F}$ & NOS & WDF & NOF & WFF & LFF & $100 \mathrm{SW}$ \\
\hline$\overline{\mathrm{LL}}$ & 0.988 & & & & & & & & & & \\
\hline LW & 0.981 & 0.987 & & & & & & & & & \\
\hline NOL & 0.954 & 0.970 & 0.931 & & & & & & & & \\
\hline SD & 0.959 & 0.981 & 0.945 & 0.997 & & & & & & & \\
\hline $50 \% \mathrm{~F}$ & 0.967 & 0.940 & 0.917 & 0.890 & 0.898 & & & & & & \\
\hline NOS & 0.955 & 0.946 & 0.971 & 0.842 & 0.867 & 0.935 & & & & & \\
\hline WDF & 0.921 & 0.904 & 0.943 & 0.778 & 0.805 & 0.910 & 0.994 & & & & \\
\hline NOF & 0.959 & 0.936 & 0.929 & 0.855 & 0.873 & 0.991 & 0.967 & 0.953 & & & \\
\hline WFF & 0.995 & 0.978 & 0.968 & 0.964 & 0.961 & 0.952 & 0.924 & 0.885 & 0.932 & & \\
\hline LFF & 0.959 & 0.919 & 0.887 & 0.910 & 0.902 & 0.979 & 0.874 & 0.839 & 0.946 & 0.964 & \\
\hline $100 \mathrm{SW}$ & 0.964 & 0.991 & 0.966 & 0.986 & 0.996 & 0.899 & 0.898 & 0.843 & 0.886 & 0.959 & 0.887 \\
\hline
\end{tabular}

PH: plant height, LL: leaf length, LW: leaf weight, NOL: number of leaves, SD: stem diameter, 50\% F: 50\% flowering, NOS: number of seeds, WDF: weight of dried fruits, NOF: number of fruits, WFF: weight of fresh fruit, and LFF: length of fresh fruit.

number of seeds per pod (Table 1). Indeed, Jagajanantham et al. [39] observed a proportionate reduction or decrease in fresh weight of bhendi variety of okra with increasing level of gamma irradiation. Weight of fresh fruit revealed a significantly $(P \leq 0.05)$ high and positive correlation with the vegetative and yield components (Table 1). The effect of 400 Gy may be due to the fact that mutagens stimulate the role of enzymes and growth regulators responsible for growth and yield. Exposure of seeds to high doses of gamma rays has been found to result in 50\% reduction in number of okra seeds produced [46]. It has also been found out that the effects of $400 \mathrm{~Gy}$ increase fruit character such as number of seeds per fruit [47]. There are also reports [48, 49] of increase in yield of crops treated with mutagens. The effects of $400 \mathrm{~Gy}$ on 100-seed weight as observed in this study could have arisen from changes in genetic material which promotes growth and yield of the plants. The positive and stimulatory effects of mutagenesis on seed weight conformed to the finding of other scientists [50-52]. A study on the effect of different doses of gamma irradiation $(10,20,30,40,50$, and $60 \mathrm{KR})$ on okra variety Arka Anamika revealed a proportionate reduction in 100 -seed weight with increasing level of gamma irradiation treatment [39].

\section{Conclusions}

Seedling survival decreased significantly $(P \leq 0.05)$ with increasing doses of gamma rays given rise to $\mathrm{LD}_{50}$ of $720 \mathrm{~Gy}$.
On the whole, 400 Gy exposure had significant $(P \leq 0.05)$ positive effects on germination, plant growth, and yield compared to $600 \mathrm{~Gy}, 800 \mathrm{~Gy}, 1000 \mathrm{~Gy}$, and the control. However, the effect of $1000 \mathrm{~Gy}$ on okra seeds tested produced the least desirable effects in almost all the evaluated characters of the okra plants. On the whole, $400 \mathrm{~Gy}$ was found suitable for promotion of healthy growth but the damaging and growth inhibitory effects of the higher doses could generate variability which can be harnessed in an $\mathrm{M}_{2}$ generation to improve the crop.

\section{Conflicts of Interest}

The authors declare that they have no conflicts of interest.

\section{References}

[1] H. F. Gemede, N. Ratta, G. D. Haki, A. Z. Woldegiorgis, and F. Beyene, "Nutritional Quality and Health Benefits of Okra (Abelmoschus esculentus)," Food Science and Quality Management, vol. 33, pp. 87-96, 2014.

[2] R. A. Holser and G. Bost, "Hybrid Hibiscus seed oil compositions," JAOCS, Journal of the American Oil Chemists' Society, vol. 81, no. 8, pp. 795-797, 2004.

[3] S. L. Kochhar, “Tropical Crops," A text Book of Economy Botany, pp. 263-264, 1981.

[4] J. A. Cook, D. J. Vanderjagt, A. Pastuszyn et al., "Nutrient and Chemical Composition of 13 Wild Plant Foods of Niger," Journal of Food Composition and Analysis, vol. 13, no. 1, pp. 83-92, 2000. 
[5] S. I. Ofoefule, A. N. Chukwu, A. Anayakohaand, and I. M. Ebebe, "Application of Abelmoschusesculentus in solid dosage forms 1: use as binder for poorly water soluble drug," IndianJournalof Pharmacy. Science, vol. 63, pp. 234-238, 2001.

[6] C. Lengsfeld, F. Titgemeyer, G. Faller, and A. Hensel, "Glycosylated Compounds from Okra Inhibit Adhesion of Helicobacter pylori to Human Gastric Mucosa," Journal of Agricultural and Food Chemistry, vol. 52, no. 6, pp. 1495-1503, 2004.

[7] J. S. Siemonsmaand and S. Hamon, "Abelmoschus, Bulletin du muscum National d", Histoire. Naturelle. Paris Seices 4, 10 sections B, Adansomiavol, vol. 2, p. 138, 2000.

[8] M. Alegbejo, "Okra Cultivars with Moderate Resistance to Okra Mosiac virus genus Tymovirus," Nigerian Journal of Horticultural Science, vol. 8, no. 1, 2004.

[9] S. D. L. Jawardena and R. Peiris, "Food crop breeding in Srilanks achievements and challenges," Biology, vol. 2, pp. 22-34, 1988.

[10] P. Donini and A. Sonnino, "Induced Mutation in Plant Breeding: Current Status and Future Outlook," in Somaclonal Variation and Induced Mutations in Crop Improvement, vol. 32 of Current Plant Science and Biotechnology in Agriculture, pp. 255291, Springer Netherlands, Dordrecht, 1998.

[11] A. Schum, "Mutation breeding in ornamentals: An efficient breeding method?" Acta Horticulturae, vol. 612, pp. 47-60, 2003.

[12] K. E. Yoon, Y. H. Park, and B. G. Im, "Effect of gamma radiation on seed germination and androgenesis in Nicotianatabacum L," Korean Journal BreedingScience, vol. 2, pp. 256-262, 1990.

[13] A. Z. Hegazi and N. Hamideldin, "The effect of gamma irradiation on enhancement of growth and seed yield of okra [Abelmoschusesculentus (L.) Monech] and associated molecular changes," Journal of Horticulture and Forestry, vol. 2, no. 3, pp. 038-051, 2010.

[14] A. K. Dubey, J. R. Yadav, and B. Singh, "Studies on induced mutations by gamma irradiation in okra (Abelmoschusesculentus(L.) Monch," 1/2, vol. 7, no. no, pp. 46-48, 2007.

[15] H. Ullah, "Estimation of Induced Variability of Yield Contributing Traits in Mlgamma Irradiated Germplasm of Okra (Abulmoschus Esculentus L.)," South Asian Journal of Life Sciences, vol. 2, no. 1, pp. 4-7, 2014.

[16] A. Kumar and M. N. Mishra, "Effect of gamma-rays, EMS and NMU on germination, seedling vigour, pollen viability and plant survival," in in M1 and M2 generation of Okra (Abelmoschusesculentus L. Moench), vol. 17, pp. 295-297, Advances in Plant Science, 2004.

[17] M. A. Haq, K. B. Singh, Z. Abidin, and M. S. Ahmad, "Mutation studies in chickpea (CicerarietinumL.). I. Mutagen sensitivity," PakistanJournal of Agricultural Science, vol. 29, no. 4, pp. 429438, 1992.

[18] S. Umavathi and L. Mullainathan, "Induced mutagenesis in Chickpea (Cicer arietinum (L.) with special reference to the frequency and spectrum of chlorophyll mutations," Journal of Applied and Advanced Research, vol. 1, no. 1, p. 49, 2016.

[19] C. Toker, B. Uzun, H. Canci, and F. Oncu Ceylan, "Effects of gamma irradiation on the shoot length of Cicer seeds," Radiation Physics and Chemistry, vol. 73, no. 6, pp. 365-367, 2005.

[20] B. S. Dhankhar and S. K Dhankhar, "Induction of genetic male sterility in okra [Abelmoschusesculentus(L.) Moench]," Crop Research, vol. 27, no. 1, pp. 111-112, 2004.

[21] R. Kumar and R. P. Sinha, "Mutagenic sensitivity of lentil genotypes," Journal of Applied Biology, vol. 13, pp. 1-5, 2003.
[22] D. S. Kumar, T. Nepolean, and A. Gopalan, "Effectiveness and efficiency of the mutagens gamma rays and ethyl methane sulfonate on limabean (Phaseoluslunatus L," Indian Journal of Agricultural Research, vol. 37, no. 2, pp. 115-119, 2003.

[23] P. F. M. Tabaresand and T. S. Talavera, "influence of different morphological charcaters on the gamma radio sensitivity of sweet potato (Ipomeabatatas L," Alinentria, vol. 40, pp. 101-104, 2003.

[24] S. Gaur, M. Singh, N. Rathore, P. S. Bhati, and D. Kumar, "Radiobiological responses of cowpea, Advances in arid-legume Research," Radiobiological responses of cowpea , Advances in arid-legume Research, pp. 75-78, 2003.

[25] P. Manju and R. Gopimony, Anjitha- A new okra variety through induced mutation in interspecific hybrids of Abelmoshus Spp. Induced plant mutations in the genomics era, Food and agriculture organization of the United Nations, 87-90, Rome, 2009.

[26] F. Norfadzrin, O. H. Ahmed, S. Shaharudin, and D. Abdul Rahman, "A preliminary study on gamma radiosensitivity of tomato (Lycopersicon esculentum) and okra (Abelmoschus esculentus)," International Journal of Agricultural Research, vol. 2, no. 7, pp. 620-625, 2007.

[27] G. Muralidharan and R. Rajendran, "Effect of Gamma rays on germination, seedling vigour, survival and pollen viability," Journal of environment Curriculum and Life Science, pp. 41-45, 2013.

[28] P. A. Kiong, L. S. H. Ling, and A. R. Grace, "Harun, Physiological responses of Orthosiphonstamineusplantlets to gamma irradiation," American Eurasian Journal Sustainable Agriculture, vol. 2, no. 2, pp. 135-149, 2008.

[29] J. Iqbal, "Radiation induced growth abnormalities in vegetative shoot apices of Capsicum annuum L. in relation to cellular damage," Radiation Botany, vol. 9, no. 6, pp. 491-499, 1969.

[30] F. Walther, "Effectiveness of mutagenic treatment with ionizing radiation in barley, induced mutation in Plants," pp. 261-270, International Atomic Energy Agency (IAEA), Vienna, 1969.

[31] A. K. Singh, K. P. Singh, and R. B. Singh, "Seedling injury, reduced pollen and ovule fertility and chlorophyll mutations induced by GAMMA RAYS and EMS in Okra (Abelmoschusesculentus L. Moench," Vegetable Science, vol. 27, no. 1, pp. 42-44, 2000.

[32] IBPGR, "Report of an International Workshop on Okra Genetic Resources , International Crop network, series 5, IBPGR," in Proceedings of the Report of an International Workshop on Okra Genetic Resources, International Crop network, series 5, IBPGR, 1991.

[33] S. J. Ochatt, P. Durieu, L. Jacas, and C. Pontecaille, "Protoplast, cell and tissue cultures forthebiotechnologicalbreeding of grass peas (Lathyrussativus L," Lathyrus and NeurolathyrismNewsletter, vol. 2, pp. 35-38, 2001.

[34] D. S. Loch, "Brachiariadecumbens (Signalgrass) A reviewwith particular referencesto Australia," Tropical grassland, vol. 11, no. 2, pp. 141-151, 1977.

[35] Anonymous, "Underexploited tropical plantswithpromisingeconomicvalue , NationalAcademy of Sciences," Washington D.C, p. $189,1975$.

[36] S. J. Khalil, S. Rehman, K. Afridiand, and M. T Jan, “Damage induced by gamma irradiation in morphological and chemical characteristics of barley," Sarhad Journal of Agriculture, vol. 2, pp. 45-54, 1986. 
[37] J. E. Gunckel and A. H. Sparrow, "Aberrantgrowth in plants induced by ionizing radiations," BrookhavenSymp Biology, vol. 6, no. 6, pp. 252-277, 1954.

[38] M. A. Pitirmovae, "Effect of gamma rays and mutagens on barley seeds," Fiziol. Res.6, vol. 12731, 1979.

[39] N. Jagajanantham, D. Dhanavel, and P. PavadaiandAl, "Growth and yield parameters using gamma rays in bhendi (Abelmoschusesculentus(L.) Moench) var. arkaanamika," 2012.

[40] NARP, "Commodity report, root and tuber crops," National Agricultural Research Project, 1994.

[41] J. P. Mishra, "Response of okra to gamma-rays," National Academy Science, vol. 22, pp. 84-85, 1999.

[42] S. Kushan and H. Mandal, "The Effect of Different Nucleation Temperatures on the Grain Morphology of $\alpha$-SiAlON Ceramics," Key Engineering Materials, vol. 237, pp. 169-174, 2003.

[43] M. N. Mishra, H. Qadri, and S. Mishra, "Macro and micro mutations," vol. 2, pp. 44-47, 2007.

[44] B. Sharma and K. Mishra, "Micro-mutations for fruit number, fruit length and fruit yield characters in gamma-irradiated generation of ANKUR-40 variety of okra. Abelmoschusesculentus L.) Monech," vol. 2, pp. 208-211, 2007.

[45] "Effect of Plant Density and Sowing Time on Growth and Yield of Mung Bean (VignaRadiata (L.) Wilczek) in Upland Rice-Mung Bean Intercropping on Land Sand Beach Samas Indonesia," International Journal of Science and Research (IJSR), vol. 5, no. 8, pp. 914-917, 2016.

[46] Woodwell, "Induced mutations-A tool in plant research," in Proceedings of the proceeding series STI/PUB/22, p. 17, 1982.

[47] G. Pushparajan, S. Sanoopand, and M. K. Harinarayanan, "Effect of gamma rays on yield attributing characters of Okra [Abelmoschusesculentus(L.) Moench]," vol. 2, pp. 535-540, 2014.

[48] S. R. A. Shamsi and S. A. Sofajy, "Effects of low doses of gamma radiation on the growth and yield of two cultivars of broad bean," Environmental and Experimental Botany, vol. 20, no. 1, pp. 87-94, 1980.

[49] K. M. Shamusuzzaman, M. M. Islamand, and B. Muwara, "Development of an early maturing chickpea variety," Breeding Newsletter and Reviews, vol. 1, p. 23, 2005.

[50] K. Sundaravadiveiu and V. R. K. Ranjithselvipand, "Induced genetic vaiabilty in cotton (Gossypiumhirsutum L) for yield and its components," Crop Research-Hisar, vol. 32, no. 3, pp. 442446, 2006.

[51] M. Zameer Khan, M. Ehsan Akhtar, M. Naeem Safdar, M. Masud Mahmood, S. Ahmad, and N. Ahmed, "Effect of source and level of potash on yield and quality of potato tubers," Pakistan Journal of Botany, vol. 42, no. 5, pp. 3137-3145, 2010.

[52] B. Singh and P. S. Datta, "Effect of low dose gamma irradiation on plant and grain nutrition of wheat," Radiation Physics and Chemistry, vol. 79, no. 8, pp. 819-825, 2010. 


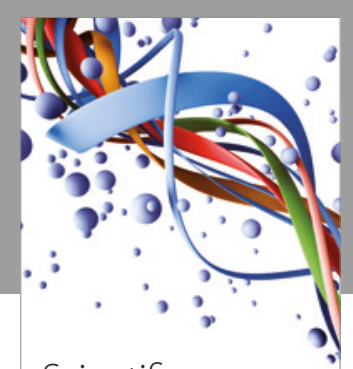

Scientifica
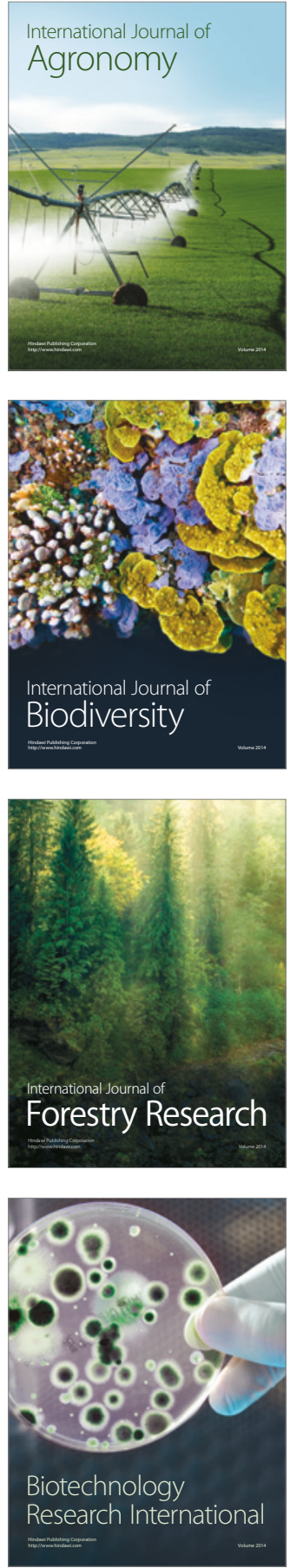
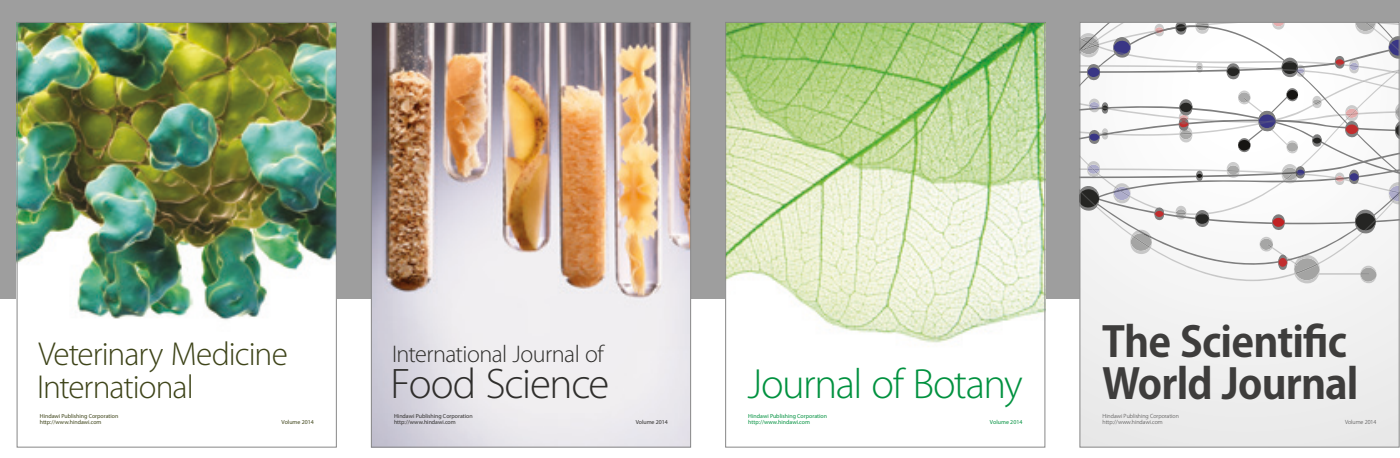

The Scientific

\section{World Journal}

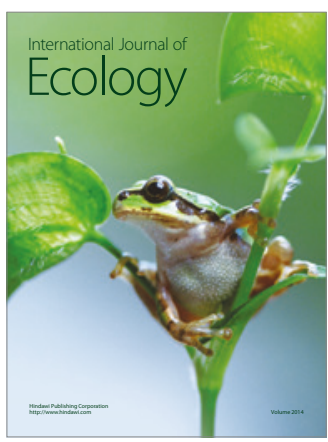

\section{Hindawi}

Submit your manuscripts at

https://www.hindawi.com
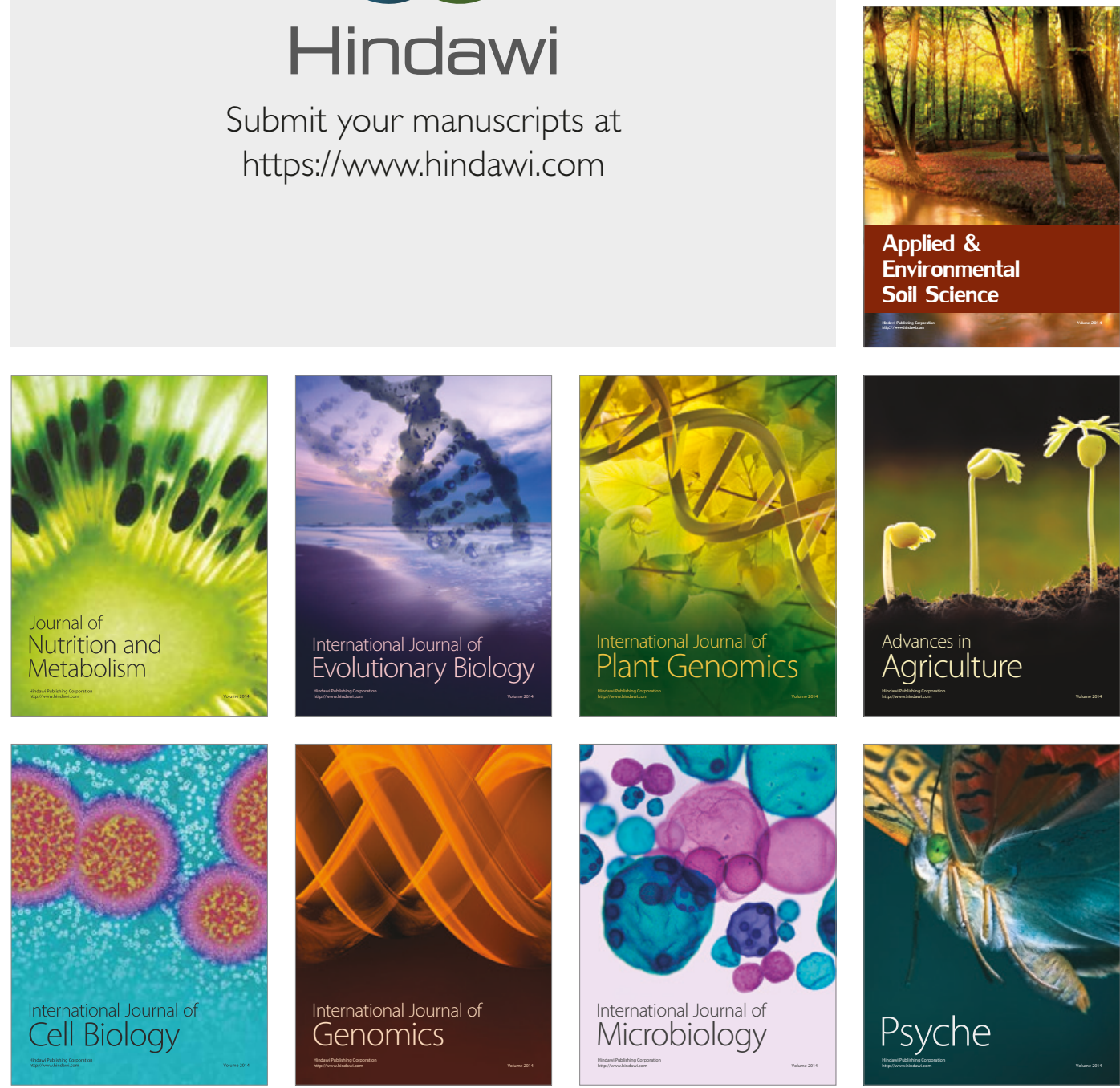

hternational Journal of Microbiology
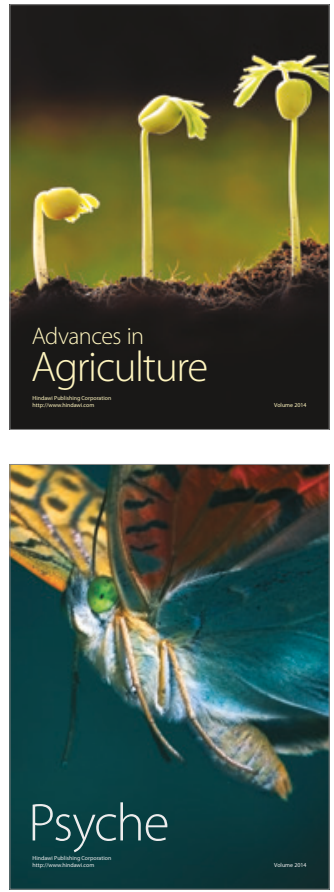